\title{
Fruit flies (Diptera: Tephritidae) and their parasitoids associated with acerola, mango, and guava in the municipality of Brasil Novo, Pará
}

\author{
Alexandra Soares de Souza ${ }^{1 *} \mathbb{D}$, José Wilson Pereira da Silva ${ }^{2}$, Beatriz Ronchi-Teles ${ }^{3}$
}

10.1590/0034-737X202168060010

\begin{abstract}
Fruit flies are phytophagous insects that are important because of the damages caused to fruits, mainly by larvae that feed on the pulp. Surveys of the diversity of these tefritids are still scarce in Brazil, especially in the Amazon region, the objective of this study was to establish the tritrophic relationship existing between species of Anastrepha, their parasitoids, and the fruits acerola (Malpighia emarginata DC.), mango (Mangifera indica L.), and guava (Psidium guajava L.) in the municipality of Brasil Novo, Pará. Freshly fallen fruits were collected weekly from January to December 2018, in three farms. Throughout the survey, 4,324 puparium were collected in guavas, 2,682 in mangoes, and 644 in acerolas. The species Anastrepha obliqua (Macquart, 1835) were identified in mango (90.3\%), acerola (7.7\%) and guava (2.1\%), and Anastrepha striata Schiner, 1868 were identified in guava (98.8\%) and acerola (1.2\%). Five species of parasitoids were identified in association with A. obliqua and six species of parasitoids were identified in association with A. striata. The specie Doryctobracon areolatus (Szépligeti, 1911) was the most frequent among the species of parasitoids recorded.
\end{abstract}

Keywords: Amazon; Anastrepha sp.; biodiversity; tritrophic relationship.

\section{INTRODUCTION}

Fruit flies (Diptera: Tephritidae) are considered insect pests of great importance in world fruit production, causing significant economic losses in production and/ or leading to increased costs and management practices of orchards (Zucchi et al., 2011). The economic losses caused by fruit fly infestation reach approximately US $\$ 1$ billion per year worldwide and US\$242 million per year in Brazil (Oliveira et al., 2013).

Damage is caused to the fruits by the females at egg laying and by the larvae feeding on the fruit pulp (Silva $e t$ al., 2013), and losses can reach $100 \%$ in some untreated orchards depending on the cultivated species (Hernandes et al., 2013).

The economically important species of Tephritidae in Brazil are separated into four genera: Anastrepha Schiner, 1968; Rhagoletis Loew, 1862; Ceratitis MacLeay, 1829; and Bactrocera Macquart, 1835. The last two are represented by a single species each, the Mediterranean fruit fly, Ceratitis capitata (Wiedemann, 1824), and the carambola fruit fly, Bactrocera carambolae (Drew \& Hancock, 1994). The genus Anastrepha is to date represented by 121 species identified throughout the Brazilian territory and infest several native and/or exotic fruits (Zucchi \& Moraes, 2008).

Knowledge about the diversity of fruit flies, host plants, and infestation rates is fundamental to define management practices for this insect pest (Silva et al., 2011). However, according to Zucchi \& Moraes (2008), only $51 \%$ of fruit flies recorded in Brazil have at least one known host.

Of the 28 Anastrepha species recorded in the state of Pará, only 11 have at least one known host plant (Adaime et al., 2016). Twenty-two host plant species were described

\footnotetext{
Submitted on September $21^{\text {th }}, 2020$ and accepted on February $17^{\text {th }}, 2021$.

'Instituto Nacional de Pesquisas da Amazônia, Programa de Pós Graduação em Agricultura no Trópico Úmido, Manaus, Amazonas, Brazil. souzaasd31@gmail.com

${ }^{2}$ Universidade Federal do Pará (UFPA), campus de Altamira, Altamira, Pará, Brazil. jwilsonps@gmail.com

${ }^{3}$ Instituto Nacional de Pesquisas da Amazônia, Coordenação de Capacitação, Manaus, Amazonas, Brazil. ronchi@inpa.gov.br

"Corresponding author: souzaasd31@gmail.com
} 
in association with Anastrepha species, in addition to $C$. capitata which is associated with four plant species (Adaime et al., 2016; Araújo et al., 2016).

Therefore, our objectives were study the tritrophic relationship between species of Anastrepha, their parasitoids, and the three commercial fruits acerola (Malpighia emarginata DC.), mango (Mangifera indica L.), and guava (Psidium guajava L.) in the municipality of Brasil Novo, state of Pará, and to determine the infestation rates and percentage of parasitism.

\section{MATERIAL AND METHODS}

The study was carried out in three farms (Santa Rita: $03^{\circ} 18^{\prime} 7.03^{\prime \prime S}$ 052 $28^{\circ} 57.98^{\prime \prime W}$; Pouso Alegre: $03^{\circ} 18^{\prime} 18.55^{\prime \prime S} 052^{\circ} 28^{\prime} 28.15^{\prime \prime W}$; Boa Vista: 0317’37.07"S $052^{\circ} 29^{\prime} 3.80^{\prime \prime} \mathrm{W}$ ) in the Municipality of Brasil Novo, MesoSouthwestern Pará (IBGE, 2017), from January to December 2018. According to the Köppen classification, the climate of the region is classified as Am - humid tropical, with average total annual rainfall ranging between $1,500 \mathrm{~mm}$ and 2,000 $\mathrm{mm}$, with the lowest rainfall rates between June and November (National Institute of Meteorology/ Ministry of Agriculture, Livestock and Supply - INMET/ MAPA, 2019).

Freshly fallen fruits from acerola, mango, and guava trees, which were not in an advanced stage of decay, hollow inside and/or half-eaten by birds and other animals, were collected weekly. The sample size varied according to fruit availability in the field, as recommended by Silva et al. (2011).

After collection, the fruits were packed in trays or plastic bags and taken to the Agricultural Entomology Laboratory (LEA) at the Federal University of Pará - UFPA, campus Altamira - PA. In the laboratory, the fruits were counted, separated, and weighed. The fruits were placed in plastic containers with the bottom covered with a layer of sterilized and moistened sand, covered with voile fabric, tightened with an elastic band or a holed lid, and kept in a protected and ventilated area.

The fruit samples were examined every five days to keep moisture and remove the puparium. The puparium were placed in a new container with a thin layer of moistened sand, covered with voile fabric tightened with an elastic band or a holed lid, and monitored daily for emergence of fruit flies and/or their parasitoids. After emergence, the insects were kept alive for 48 hours, so that their morphological structures acquired a peculiar color, which is important for taxonomic identification. Then, the insects were sorted by sex, counted, and stored in $70 \%$ alcohol until species identification, as recommended de Silva et al. (2011).

The insects were identified at the Agriculture Insect Rearing Laboratory of the National Research Institute of the Amazon (INPA). The adult females collected from the fruits were analyzed according to the wing and thoracic patterns and morphometric measurements of the aculeus apex, according to the dichotomous keys by Zucchi (2000) and Zucchi et al. (2011).

The parasitoids of the Braconidae family were identified based on the shape of the mandible and the clypeus, structure and color of the wing and the propodeum (Marinho et al., 2011). The individuals of the Figitidae family were analyzed based on the characteristics of the antenna, thorax, and anterior wing venation (Guimarães \& Zucchi, 2011). The individuals of the Pteromalidae family were identified based on the legs, wings and antennae (Wharton \& Yoder, 2019). The voucher specimens of fruit flies and parasitoids sampled were deposited in the Biological Scientific Collections at INPA.

The parameters evaluated were the indices of infestation per kilogram of fruit, pupal viability (PV), parasitism rate (PT), and frequency of parasitoids per species (F). Calculations were made according to Sá et al. (2008) (infestation rates); Souza et al. (2005) (pupal viability); Araújo et al. (2015) (parasitism rate); Araújo et al. (2014) (frequency of parasitoids per species).

\section{RESULTS AND DISCUSSION}

A total of 4,103 fruits of acerola, mango, and guava were collected, corresponding to $122.3 \mathrm{~kg}$, from which 7,650 puparium of fruit flies were obtained, the majority from samples of guava with 4,324 puparium, followed by mango with 2,682 puparium, and acerola with 644 puparium.

Two species of fruit flies were identified infesting the fruits sampled: 1,339 individuals of Anastrepha obliqua (Macquart, 1835) and 438 individuals of Anastrepha striata Schiner, 1868. A. obliqua infested the samples of all fruit species, with frequencies of $90.3 \%$ in mangoes, $7.7 \%$ in acerolas and $2.1 \%$ in guavas, while $A$. striata infested guavas and acerolas, with frequencies of $98.8 \%$ and $1.2 \%$, respectively.

The species A. striata is an important native agricultural pest that occurs in the Amazon region and has guava as its main host (Jesus-Barros et al., 2012). This is the first record of $A$. striata infesting acerola fruits in the state of Pará, and there is only one record of infestation of this fruit in the Amazon region, in Ilha de Santana, AP, by Almeida et al. (2016).

The species A. obliqua is predominant in the Amazon region, since the species has a polyphagous feeding habit and infest several host plants (Zucchi \& Moraes, 2008). However, it preferentially attacks plants in the family Anacardiaceae (Ferreira et al., 2003). In the Amazon region, this species is described as infesting 33 species of host plants belonging to eight botanical families Anacardiaceae, Apocynaceae, Chrysobalanaceae, 
Combretaceae, Malpighiaceae, Myrtaceae, Oxalidaceae and Sapotaceae. (Adaime et al., 2016).

The average fruit-fly infestation rates in the guava samples were 3.3 puparium/fruit and 110.8 puparium $/ \mathrm{kg}$ (Table 1). The average infestation rate/kg was higher than those reported by other studies such as the survey carried out by Santos et al. (2012), in which they found infestation of 99.3 puparium $/ \mathrm{kg}$ in collections carried out in organic guava crops in the municipality of Maceió, Alagoas. Similarly, Moura \& Moura (2011) found infestation levels lower than the findings of the present study, reporting 30.3 puparium $/ \mathrm{kg}$ in samples collected in a guava orchard in Fortaleza, Ceará.

The average pupal viability (PV) in the guava samples was $63.2 \%$ (Table 1). This result is lower than the PV found by Dias et al. (2013) in a survey carried out in municipalities along the border area of Rio Grande do Sul, Argentina and Uruguay, where, in guava fruits, the PV of A. fraterculus was $76 \%$ and C. capitata was $85 \%$. However, the result of this study was higher than that reported by Santos et al. (2012) for organic guava crops in the municipality of Maceió, Alagoas, where they found VP of 59.6\%.

In this study, the PV found for guava fruits was higher than the other fruits. According to Sá et al. (2008), a high pupal viability is not desirable in pest management, because hosts that allow good larval performance contribute to the maintenance and increase of the fruit fly population; therefore, as it is a potential host for fruit fly, the guava crop should have special attention.

The average rates of infestation by fruit flies in the mango samples were 4.8 puparium/fruit and 34.9 puparium $/ \mathrm{kg}$ (Table 2). These rates were higher than the reports of Sousa et al. (2019) for mango of Tommy Atkins variety, with infestation rates of 4.1 puparium $/ \mathrm{kg}$. However, they were lower than the infestation rates Raga et al. (2011) found in a survey carried out in 67 municipalities in the state of São Paulo, 59 puparium/ fruit and 283.3 puparium $/ \mathrm{kg}$.

Acerola fruits showed the lowest infestation per fruit, with mean of 0.3 puparium/fruit, which is probably due to their smaller size (Table 3). Leite et al. (2017) report infestation rate of 0.04 puparium/fruit in Nossa Senhora do Livramento, BA, while Araújo et al. (2011) describe infestation rates of 0.01 to 0.91 puparium/fruit in Mossoró, RN.

The average PV obtained in the present study in the acerola samples was $21.8 \%$ (Table 3 ), which was close to that observed by Lemos et al. (2017) in surveys carried out in commercial orchards in the state of Amapá, where PV was $20 \%$. However, our results were inferior to the reports of other studies. Almeida et al. (2016) carried out a survey in three municipalities in the state of Amapá and found PV of 58\%; Marsaro Júnior et al. (2011) carried out a survey five municipalities in the state of Roraima and found PV of $71 \%$.

The lowest PV was recorded in the samples of acerola, which may indicate a low preference for this fruit by the Anastrepha species compared with the other fruits studied in this work. Another reason that may have influenced VP and If is the high level of parasitism in relation to other fruit.

Of the 599 parasitoids that emerged in the collected samples, 292 were found in guavas, 205 in mangoes, and 102 in acerolas. The species associated with $A$. striata in guava were the family Figitidae (Aganaspis pelleranoi (Brèthes, 1924)); the family Braconidae (Doryctobracon areolatus (Szépligeti, 1911), Odontosema albinerve

Table 1: Infestation rates by Anastrepha species in commercial crop of guava (Psidium guajava, Myrtaceae) in the municipality of Brasil Novo, state of Pará, Brazil, January to December 2018. If: Infestation per fruit; Ifk: Infestation per kilogram of fruit; PV (\%): pupal viability

\begin{tabular}{lccccccccc}
\hline Farm & $\mathbf{N}^{\mathbf{0}}$ Fruits & Weight $(\mathbf{k g})$ & Pupae & Males & A. striata & A. obliqua & If & Ifk & PV $(\%)$ \\
\hline Santa Rita & 310 & 7.4 & 961 & 201 & 250 & 1 & 3.1 & 129 & 55.8 \\
Pouso Alegre & 598 & 17.5 & 2.366 & 774 & 783 & 0 & 4 & 135.4 & 68.8 \\
Boa Vista & 336 & 14.7 & 997 & 323 & 290 & 9 & 3 & 68 & 64.9 \\
\hline Total & 1,244 & 39.6 & 4,324 & 1,298 & 1,323 & 10 & 3.3 & 110.8 & 63.2 \\
\hline
\end{tabular}

Table 2: Infestation rates by Anastrepha species in commercial crop of mango (Mangifera indica, Anacardiaceae) in the municipality of Brasil Novo, state of Pará, Brazil, January to December 2018. If: Infestation per fruit; Ifk: Infestation per kilogram of fruit; PV (\%): pupal viability

\begin{tabular}{lccccccccc}
\hline Farm & $\mathbf{N}^{\mathbf{0}}$ Fruits & Weight $(\mathbf{k g})$ & Pupae & Males & A. striata & A. obliqua & If & Ifk & PV $(\%)$ \\
\hline Santa Rita & 237 & 29.4 & 810 & 116 & 0 & 89 & 3.4 & 27.6 & 26 \\
Pouso Alegre & 21 & 3.7 & 67 & 3 & 0 & 17 & 3.2 & 17.9 & 30.3 \\
Boa Vista & 230 & 30.6 & 1.805 & 339 & 0 & 330 & 7.8 & 59.1 & 41.3 \\
\hline Total & 488 & 63.7 & 2,682 & 458 & 0 & 436 & 4.8 & 34.9 & 32.5 \\
\hline
\end{tabular}


Table 3: Infestation rates by Anastrepha species in commercial crop of acerola (Malpighia emarginata, Malpighiaceae) in the municipality of Brasil Novo, state of Pará, Brazil, January to December 2018. If: Infestation per fruit; Ifk: Infestation per kilogram of fruit; PV (\%): pupal viability

\begin{tabular}{lccccccccc}
\hline Farm & $\mathbf{N}^{\mathbf{0}}$ Fruits & Weight $(\mathbf{k g})$ & Pupae & Males & A. striata & A. obliqua & If & Ifk & PV $(\%)$ \\
\hline Santa Rita & 539 & 1.7 & 163 & 11 & 0 & 7 & 0.3 & 94.6 & 13.1 \\
Pouso Alegre & 598 & 5.1 & 387 & 52 & 4 & 26 & 0.3 & 75.4 & 25.4 \\
Boa Vista & 336 & 2.2 & 94 & 6 & 12 & 4 & 0.2 & 43.1 & 26.8 \\
\hline Total & 1,473 & 9 & 644 & 69 & 16 & 37 & 0.3 & 71 & 21.8 \\
\hline
\end{tabular}

Kieffer, 1909, Opius bellus (Gahan, 1930), Utetes anastrephae (Viereck, 1913)); and the family Pteromalidae (Pachycrepoideus vindemmiae (Rondani, 1875)) (Table 4). The results found in this study agree with those of Jesus-Barros et al. (2012), who found that these species were associated with A. striata in surveys carried out in five municipalities in the state of Amapá and surveys carried out by Dutra et al. (2013) in the state of Amazonas.

The parasitoid species A. pelleranoi, D. areolatus, $O$. albinerve, $O$. bellus, and $U$. anastrephae associated with A. obliqua were found in mango fruits. The two species of parasitoids $D$. areolatus and $U$. anastrephae associated with A. obliqua were recorded in acerola fruits (Table 4). These species were also found associated with A. obliqua in the survey carried out by Marsaro Júnior et al. (2011) in

Table 4: Tritrophic relationships observed between species of parasitoids, fruit flies and host fruits collected in three properties in the municipality of Brasil Novo, state of Pará, Brazil, JanuaryDecember / 2018

\begin{tabular}{lll}
\hline Fruit Fly & Fruit & Species parasitoids \\
\hline Anastrepha striata & Guava & Doryctobracon areolatus \\
& & Aganaspis pelleranoi \\
& & Utetes anastrephae \\
& Pachycrepoideus vindemmiae \\
& Odontosema albinerve \\
& & Opius bellus \\
\hline Anastrepha obliqua & Mango & Doryctobracon areolatus \\
& & Utetes anastrephae \\
& & Odontosema albinerve \\
& & Aganaspis pelleranoi \\
& & Opius bellus \\
\hline Acerola & Doryctobraconareolatus \\
& & Utetes anastrephae \\
\hline
\end{tabular}

the state of Roraima and by Sousa et al. (2016) in three municipalities in the state of Amapá.

The average parasitism rate in guava samples was $8 \%$ (Table 5). The results were close to those found by Leal $\mathrm{et}$ al. (2009), who recorded levels of parasitism from 1.5 to $11.5 \%$ in surveys carried out in four municipalities in the state of Rio de Janeiro. Further, the results of the present study were higher than that reported by Bittencourt et al. (2012) for surveys in garden orchards in the Southcoast of Bahia, in which the authors observed parasitism rate of 1.61 in guava samples.

The average parasitism rate in mango fruits was $4.8 \%$ (Table 6), the lowest in relation to the other fruits studied, a result close to that found by Marinho et al. (2009). The factors that can initially interfere in parasitism are the volatiles of infested fruits (Eitam et al., 2003), the removal of fruits from the field to the laboratory, but a characteristic that can directly affect the parasitism index is the morphology of the fruit because in smaller fruits with shallow pulp the indexes are higher in relation to large fruits (Hickel, 2002).

The average parasitism rate in acerola was $15.1 \%$ (Table 7 ), which was higher than the rates recorded in the other fruit species sampled, probably due to the small size of the fruit. According to Nascimento et al. (2015), parasitism is influenced by the physical characteristics of the fruit, with the highest rates occurring in small-sized fruits as in the case of Spondias mombin L.

In general, parasitism rates are low, but varies according to location and host species in the area (Carvalho et al., 2010), therefore, the selection of plant hosts with high rates of parasitism should be considered for planting in fruit growing areas, aiming to increase natural parasitism of fruit flies (Silva et al., 2013).

Table 5: Parasitism indexes of Anastrepha species in guava fruits Psidium guajava (Myrtaceae) in three properties in the municipality of Brasil Novo, state of Pará, Brazil, January to December 2018

\begin{tabular}{lccc}
\hline Farm & $\mathbf{N}^{\circ}$ Pupae & $\mathbf{N}^{\mathbf{0}}$ Parasitoids & Parasitism $(\boldsymbol{\%})$ \\
\hline Santa Rita & 961 & 151 & 15.7 \\
Pouso Alegre & 2,366 & 103 & 4.4 \\
Boa Vista & 997 & 38 & 3.8 \\
\hline Total & 4,324 & 292 & 8 \\
\hline
\end{tabular}

Rev. Ceres, Viçosa, v. 68, n.6, p. 579-585, nov/dec, 2021 
Table 6: Parasitism indexes of Anastrepha species in mango fruits Mangifera indica (Anacardiaceae) in three properties in the municipality of Brasil Novo, state of Pará, Brazil, January to December 2018

\begin{tabular}{lccc}
\hline Farm & $\mathbf{N}^{\circ}$ Pupae & $\mathbf{N}^{\mathbf{0}}$ Parasitoids & Parasitism $(\boldsymbol{\%})$ \\
\hline Santa Rita & 810 & 23 & 2.8 \\
Pouso Alegre & 67 & 1 & 1.5 \\
Boa Vista & 1,805 & 181 & 10 \\
\hline Total & 2,682 & 205 & 4.8 \\
\hline
\end{tabular}

Table 7: Parasitism indexes of Anastrepha species in acerola fruits Malpighia emarginata (Malpighiaceae) in three properties in the municipality of Brasil Novo, state of Pará, Brazil, January to December 2018

\begin{tabular}{lccc}
\hline Farm & $\mathbf{N}^{\circ}$ Pupae & $\mathbf{N}^{\mathbf{0}}$ Parasitoids & Parasitism $(\%)$ \\
\hline Santa Rita & 163 & 26 & 16 \\
Pouso Alegre & 387 & 64 & 16.5 \\
Boa Vista & 94 & 12 & 12.8 \\
\hline Total & 644 & 102 & 15.1 \\
\hline
\end{tabular}

Table 8: Frequency of parasitoids (\%) in guava, mango and acerola fruits collected in three properties in the municipality of Brasil Novo, state of Pará, Brazil, January-December / 2018

\begin{tabular}{|c|c|c|c|c|c|}
\hline \multicolumn{6}{|c|}{ Frequency of parasitoids (\%) } \\
\hline \multirow{2}{*}{ Fruit } & \multirow{2}{*}{ Species } & \multicolumn{3}{|c|}{ Farm } & \multirow{2}{*}{ Total } \\
\hline & & Santa Rita & Pouso Alegre & Boa Vista & \\
\hline \multirow[t]{6}{*}{ Guava } & Doryctobracon areolatus & 27.2 & 76.7 & 68.4 & 57.4 \\
\hline & Aganaspis pelleranoi & 66.2 & 19.4 & 18.4 & 34.7 \\
\hline & Utetes anastrephae & - & 1.9 & 10.5 & 4.2 \\
\hline & Odontosema albinerve & 2.0 & 1.9 & 2.6 & 2.2 \\
\hline & Pachycrepoideus vindemmiae & 4.0 & - & - & 1.3 \\
\hline & Opius bellus & 0.7 & - & - & 0.2 \\
\hline \multirow[t]{5}{*}{ Mango } & Doryctobracon areolatus & 95.7 & - & 79.6 & 58.4 \\
\hline & Aganaspis pelleranoi & - & 100 & 11.6 & 37.2 \\
\hline & Utetes anastrephae & 4.3 & - & 6.1 & 3.5 \\
\hline & Odontosema albinerve & - & - & 2.2 & 0.7 \\
\hline & Opius bellus & - & - & 0.6 & 0.2 \\
\hline \multirow[t]{5}{*}{ Acerola } & Doryctobracon areolatus & 42.3 & 73.4 & 66.7 & 60.8 \\
\hline & Aganaspis pelleranoi & 34.6 & 3.1 & 16.7 & 18.1 \\
\hline & Utetes anastrephae & 11.5 & 20.3 & 16.7 & 16.2 \\
\hline & Pachycrepoideus vindemmiae & 7.7 & - & - & 2.6 \\
\hline & Opius bellus & 3.8 & 3.1 & - & 2.3 \\
\hline
\end{tabular}

Among the parasitoids observed, D. areolatus presented the highest frequency in all the fruits studied, varying between 57.4 to $60.8 \%$, followed by $A$. pelleranoi, varying from 18.1 to $58.4 \%$, and $U$. anastrephae, varying from 3.5 to $16.2 \%$ (Table 8 ). Several surveys conducted in Brazil showed that $D$. areolatus is the most frequent species in collections of fruit flies, which is due to the size of its ovipositor and egg-laying performance at different stages from immature eggs to third-instar larvae (Marinho et al., 2011; Nunes et al., 2011).

\section{CONCLUSIONS}

Two species of Anastrepha were identified infesting the collected fruit samples, A. obliqua in fruits of mango (90.3\%), acerola (7.7\%) and guava (2.1\%), and A. striata in guava $(98.8 \%)$ and acerola $(1.2 \%)$.

Guava was the most susceptible crop to fruit fly infestation among the three fruit species studied.

This is the first record of $A$. striata infesting acerola (Malpighia emarginata) fruits in the state of Pará and

Rev. Ceres, Viçosa, v. 68, n.6, p. 579-585, nov/dec, 2021 
second record in Brazil, adding to the existing list of hosts of this insect pest.

Doryctobracon areolatus was the most frequent parasitoid species in all samples of the fruits collected, providing important information for the management of fruit flies.

\section{ACKNOWLEDGEMENTS}

The authors thank the Instituto Nacional de Pesquisas da Amazônia (INPA) and the Universidade Federal do Pará (UFPA) for the support given to the research and the Coordenação de Aperfeiçoamento de Pessoal de Nível Superior (CAPES) for granting the master's degree scholarship. We also thank the anonymous reviewers and the academic editor for improving the manuscript. There was no conflict of interests in carrying the research and the paper is available for full disclosure.

\section{REFERENCES}

Adaime R, Sousa MSM \& Pereira JF (2016) Anastrepha species and their host in the Brazilian Amazon. Available at: https:// anastrepha.cpafap.embrapa.br. Accessed on: March 20 ${ }^{\text {th }}, 2019$.

Almeida RR, Cruz KR, Sousa MSM, Costa Neto SV, Jesus Barros CR, Lima AL \& Adaime R (2016) Frugivorous flies (Diptera: Tephritidae, Lonchaeidae) associated with fruit production on Ilha de Santana, Brazilian Amazon. Florida Entomologist, 99:426-436.

Araújo AAR, Silva PRR, Querino RB, Sousa EPS \& Soares LL (2014) Moscas-das-frutas (Diptera: Tephritidae) associadas às frutíferas nativas de Spondias spp. (Anacardiaceae) e Ximenia americana L. (Olacaceae) e seus parasitoides no Estado do Piauí, Brasil. Semina: Ciências Agrárias, 35:1739-1750.

Araújo EL, Fernandes EC, Silva RIR, Ferreira ADCL \& Costa VD (2015) Parasitoides (Hymenoptera) de moscas-das-frutas (Diptera: Tephritidae) no semiárido do estado do Ceará, Brasil. Revista Brasileira de Fruticultura, 37:610-616.

Araújo EL, Lopes PDR, Gomes JD, Bittencourt MAL \& RonchiTeles B (2011) Índices de captura e infestação da mosca do mediterrâneo em acerola comum e clonada. Revista Verde, 6:5864.

Araújo MR, Lemos WP, Silva LC, França LPN \& Adaime R (2016) New host records for Ceratitis capitata (Diptera Tephritidae) in the state of Pará, Brazil. Florida Entomologist, 99:327-328.

Bittencourt MAL, Santos OO, Brito EA, Araújo EL \& Marinho CF (2012) Parasitóides (Braconidae) associados à Anastrepha (Tephritidae) em frutos hospedeiros do Litoral Sul da Bahia. Revista Ciência Agronômica, 43:811-815.

Carvalho RS, Soares Filho WS \& Ritzinger R (2010) Umbu-cajá como repositório natural de parasitoide nativo de moscas-dasfrutas. Pesquisa Agropecuária Brasileira, 45:1222-1225.

Dias NP, Silva FFD, Abreu JAD, Pazini JDB \& Botta RA (2013) Nível de infestação de moscas-das-frutas em faixa de fronteira, no Rio Grande do Sul. Revista Ceres, 60:589-593.

Dutra VS, Ronchi-Teles B, Garcia MVB, Adaime R \& Silva JG (2013) Native hosts and parasitoids associated with Anastrepha fractura and other Anastrepha species (Diptera: Tephritidae) in the Brazilian Amazon. Florida Entomologist, 96:270-273.
Eitam A, Holler T, Sivinski J \& Aluja M (2003) Use of host fruit chemical cues for laboratory rearing of Doryctobracon areolatus (Hymenoptera: Braconidae), a parasitoid of Anastrepha spp. (Diptera: Tephritidae). Florida Entomologist, 86:211-212.

Ferreira HJ, Veloso VRS, Naves RV \& Braga Filho JR (2003) Infestação de moscas-das-frutas em variedades de manga (Mangifera indica L.) no Estado de Goiás. Pesquisa Agropecuária Tropical (UFG), 33:43-48.

Guimarães JA \& Zucchi RA (2011) Chave de identificação de Figitidae (Eucoilinae) parasitoides de larvas frugívoras na região Amazônica. In: Silva RA, Lemos WP \& Zucchi RA (Ed.) Moscas-das-frutas na Amazônia brasileira: diversidade, hospedeiros e inimigos naturais. Macapá, Empresa Brasileira de Pesquisa Agropecuária. p.103-109.

Hernandes JL, Blain GC \& Pedro Júnior MJ (2013) Controle de moscas-das-frutas (Diptera: Tephritidae) em cultivo orgânico de ameixa pelo ensacamento dos frutos com diferentes materiais. Revista Brasileira de Fruticultura, 35:1209-1213.

Hickel E R (2002) Espessura da polpa como condicionante do parasitismo de mosca-das-frutas (Diptera: Tephritidae) por Hymenoptera: Braconidae. Ciência Rural 32:1005-1009.

Instituto Brasileiro de Geografia e Estatística - IBGE (2017) Levantamento Sistemático da Produção Agrícola 2017. Available at: https://censos.ibge.gov.br/agro/2017/. Accessed on: January $10^{\text {th }}, 2019$.

Instituto Nacional de Meteorologia/Ministério da Agricultura Pecuária e Abastecimento - INMET/MAPA (2019) Banco de Dados Meteorológicos para Ensino e Pesquisa. Available at: https:/ /portal.inmet.gov.br/. Accessed on: March 08 $8^{\text {th }}, 2019$.

Jesus-Barros CR, Adaime R, Oliveira MN, Silva WR, Costa-Neto SV \& Souza-Filho MF (2012) Anastrepha (Diptera: Tephritidae) species, their hosts and parasitoids (Hymenoptera: Braconidae) in five municipalities of the state of Amapá, Brazil. Florida Entomologist, 95:694-705.

Leal MR, Souza SADS, Aguiar-Menezes EDL, Lima Filho M \& Menezes EB (2009) Diversidade de moscas-das-frutas, suas plantas hospedeiras e seus parasitóides nas regiões Norte e Noroeste do Estado do Rio de Janeiro, Brasil. Ciência Rural, 39:627-634.

Leite SA, Castellani MA, Ribeiro AEL, Costa DRD, Bittencourt MAL \& Moreira AA (2017) Fruit flies and their parasitoids in the fruit growing region of Livramento de Nossa Senhora, Bahia, with records of unprecedented interactions. Revista Brasileira de Fruticultura, 39:e-592.

Lemos LN, Deus EDG, Nascimento DB, Jesus-Barros CR, CostaNeto SV \& Adaime R (2017) Species of Anastrepha (Diptera: Tephritidae), their host plants, and parasitoids in small fruit production areas in the state of Amapá, Brazil. Florida Entomologist, 100:403-411.

Marinho CF, Souza-Filho MF, Raga A \& Zucchi RA (2009) Parasitóides (Hymenoptera: Braconidae) de moscas-das-frutas (Diptera: Tephritidae) no Estado de São Paulo: plantas associadas e parasitismo. Neotropical Entomology, 38:321-326.

Marinho CF, Silva RA \& Zucchi RA (2011) Chave de identificação de Braconidae (Alysiinae e Opiinae) parasitoides de larvas frugívoras na região Amazônica. In: Silva RA, Lemos WP \& Zucchi RA (Ed.) Moscas-das-frutas na Amazônia brasileira: diversidade, hospedeiros e inimigos naturais. Macapá, Empresa Brasileira de Pesquisa Agropecuária. p.91-102.

Marsaro Júnior AL, Adaime R, Ronchi-Teles B, Lima CR \& Pereira PRVDS (2011) Anastrepha species (Diptera: Tephritidae), their hosts and parasitoids in the extreme north of Brazil. Biota Neotropica, 11:117-124. 
Moura AD \& Moura DD (2011) Levantamento e flutuação populacional de parasitóides de moscas-das-frutas (Diptera: Tephritidae) de ocorrência em goiabeira (Psidium guajava L.) em Fortaleza, Ceará. Arquivos do Instituto Biológico, 78:225231.

Nascimento DB, Adaime R, Cunha A \& Silva J (2015) Influência dos parâmetros biométricos de frutos de Spondias mombin L. sobre os índices de infestação por Anastrepha spp. (Diptera: Tephritidae) e parasitismo. Biota Amazônia (Biote Amazonie, Biota Amazonia, Amazonian Biota), 5:83-87.

Nunes AM, Nava DE, Müller FA, Gonçalves RS \& Garcia MS (2011) Biology and parasitic potential of Doryctobracon areolatus on Anastrepha fraterculus larvae. Pesquisa Agropecuária Brasileira, 46:669-671.

Oliveira CM, Auad AM, Mendes SM \& Frizzas MR (2013) Economic impact of exotic insect pests in Brazilian agriculture. Journal of Applied Entomology, 137:1-15.

Raga A, Souza-Filho MF, Machado RA, Sato ME \& Siloto RC (2011) Host ranges and infestation indices of fruit flies (Tephritidae) and lance flies (Lonchaeidae) in São Paulo State, Brazil. Florida Entomologist, 94:787-795.

Sá RF, Castellani MA, Nascimento AS, Brandão MHDST, Silva AN \& Pérez-Maluf R (2008) Índice de infestação e diversidade de moscas-das-frutas em hospedeiros exóticos e nativos no pólo de fruticultura de Anagé, BA. Bragantia, 67:401-411.

Santos JRT, Broglio SMF, Santos JM, Batista NS, Costa SS \& Santos DS (2012) Infestação e viabilidade pupal de moscas-dasfrutas do gênero Anastrepha (Diptera: Tephritidae) associado a myrtaceas em cultivo orgânico no município de Maceió, AL. Cadernos de Agroecologia, 6:1-4.

Silva RA, Lima AL \& Deus EDG (2013) Controle biológico de moscas-das-frutas na Amazônia: um caminho para desenvolvimento sustentável da fruticultura. Inclusão Social, 6:90-99.
Silva RA, Deus EG, Raga A, Pereira JDB, Souza Filho MF \& Costa Neto SV (2011) Monitoramento de moscas-das-frutas na Amazônia: amostragem de frutos e uso de armadilhas. In: Silva RA, Lemos WP \& Zucchi RA (Ed.) Moscas-das-frutas na Amazônia brasileira: diversidade, hospedeiros e inimigos naturais. Macapá, Empresa Brasileira de Pesquisa Agropecuária. p.33-50.

Sousa MDSM, Jesus Barros CR, Yokomizo GKI, Lima AL \& Adaime R (2016) Ocorrência de moscas-das-frutas e parasitoides em Spondias mombin L. em três municípios do estado do Amapá, Brasil. Biota Amazônia, 6:50-55.

Sousa MMD, Araujo EL, Silva JG, Barbosa DRS \& Fernandes EC (2019) Fruit flies (Diptera: Tephritidae) in commercial mango orchards in a semiarid region of Brazil. Revista Brasileira de Fruticultura, 41:e-347.

Souza SA, Resende AL, Strikis PC, Costa JR, Ricci MS \& AguiarMenezes EL (2005) Infestação natural de moscas frugívoras (Diptera: Tephritoidea) em café arábica, sob cultivo orgânico arborizado e a pleno sol, em Valença, RJ. Neotropical Entomology, 34:639-648.

Wharton R.A \& Yoder MJ (2019) Parasitoids of Fruit-Infesting Tephritidae. Available at: http://paroffit.org/public/site/paroffit/ home. Accessed on: March 19 2019.

Zucchi RA \& Moraes RCB (2008) Fruit flies in Brazil Anastrepha species their host plants and parasitoids. Available at: www.lea.esalq.usp.br/anastrepha/. Accessed on: April $18^{\text {th }}$ 2019.

Zucchi RA (2000) Taxonomia. In: Malavasi A \& Zucchi R (Ed.) Moscas-das-frutas de importância econômica no Brasil: conhecimento básico e aplicado. Ribeirão Preto, Holos. p.13-24.

Zucchi RA, Uramoto K \& Souza-Filho MF (2011) Chave ilustrada para as espécies de Anastrepha da região Amazônica. In: Silva RA, Lemos WP \& Zucchi RA (Ed.) Moscas-das-frutas na Amazônia brasileira: diversidade, hospedeiros e inimigos naturais. Macapá, Empresa Brasileira de Pesquisa Agropecuária. p.7191. 